\title{
Pengaruh Sanksi Pajak dan Kesadaran Wajib Pajak pada Kepatuhan Wajib Pajak
}

\author{
I Gusti Bagus Putra Pranata1 \\ Fakultas Ekonomi dan Bisnis \\ Universitas Udayana, Indonesia. \\ Email: putrapranata848@gmail.com
}

\author{
I Ketut Jati ${ }^{2}$ \\ Fakultas Ekonomi dan Bisnis \\ Universitas Udayana, Indonesia.
}

\begin{abstract}
ABSTRAK
Tujuan penelitian ini adalah untuk mengetahui pengaruh sanksi pajak dan kesadaran wajib pajak pada kepatuhan wajib pajak badan. Penelitian dilakukan di Kantor Pelayanan Pajak Pratama Gianyar. Jumlah sampel yang diambil sebanyak 100 wajib pajak badan, dengan metode convenience sampling. Metode convenience sampling adalah pengambilan sampel yang dilakukan secara acak dengan mempertimbangkan kemudahan akses yang dapat dijangkau oleh peneliti. Teknik analisis yang digunakan adalah regresi linear berganda. Hasil penelitian memberikan makna bahwa semakin tinggi sanksi pajak, maka semakin tinggi tingkat kepatuhan wajib pajak, begitu juga sebaliknya. Berdasarkan hasil penelitian ini kesadaran wajib pajak berpengaruh positif pada kepatuhan wajib pajak sehingga hipotesis kedua dalam penelitian ini diterima.
\end{abstract}

Kata Kunci : $\quad$ Pajak; Wajib Pajak; Sanksi; Kesadaran; Kepatuhan.

\section{Effects of Tax Sanctions and Taxpayer Awareness on the Compliance of Corporate Taxpayers}

\section{ABSTRACT}

The purpose of this study was to determine the effect of tax sanctions and taxpayer awareness on corporate taxpayer compliance. The study was conducted at the Gianyar Pratama Tax Service Office. The number of samples taken as many as 100 corporate taxpayers, by convenience sampling method. Convenience sampling method is sampling taken randomly by considering the ease of access that can be reached by researchers. The analysis technique used is multiple linear regression. The results of the study mean that the higher the tax sanction, the higher the level of taxpayer compliance, and vice versa. Based on the results of this study the awareness of taxpayers has a positive effect on taxpayer compliance so that the second hypothesis in this study is accepted.

Keywords : $\quad$ Taxes; Taxpayers; Sanctions; Awareness; Compliance.

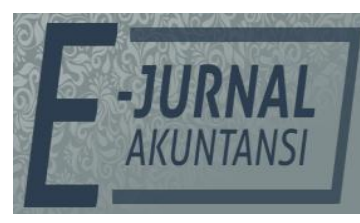

E-JA

e-Jurnal Akuntansi e-ISSN 2302-8556

Vol. 29 No. 1 Denpasar, Oktober 2019 Hal. 158-172

Artikel masuk: 04 Juli 2019

Tanggal diterima: 18 September 2019 


\section{PENDAHULUAN}

Pembangunan Nasional merupakan kegiatan yang berlangsung secara terusmenerus dan berkesinambungan yang bertujuan untuk meningkatkan kesejahteraan rakyat baik materiil maupun spiritual, sehingga untuk dapat merealisasikan tujuan tersebut, diperlukan perhatian khusus atas masalah dalam pembiayaan pembangunan infrastruktur negara.

Indonesia merupakan salah satu negara yang sedang berkembang, dimana memerlukan anggaran yang cukup besar setiap tahunnya untuk mewujudkan berbagai macam pembangunan. Semakin besar pengeluaran pemerintah untuk pembangunan infrastruktur negara, maka semakin besar pula penerimaan yang harus didapatkan. Terdapat 2 (dua) sumber penerimaan negara yaitu penerimaan dalam negeri dan pinjaman luar negeri. Sumber pendapatan negara yang berasal dari dalam negeri dibagi menjadi 3 (tiga) yaitu Penerimaan Negara Bukan Pajak (PNBP), penerimaan pajak, serta hibah.

Sektor penerimaan pajak merupakan salah satu sumber utama yang diandalkan pemerintah dalam membiayai pembangunan serta pengeluaranpengeluaran belanja negara. Santika, (2015) mengatakan bahwa pajak merupakan kekayaan potensial yang dimiliki oleh setiap daerah dan hampir seluruh daerah di Indonesia menggali potensi pendapatan daerahnya dengan memungut pajak. Jumlah penduduk Indonesia yang setiap tahunnya semakin bertambah menyebabkan sumber penerimaan pemerintah dari sektor perpajakan dikatakan sebagai sumber penerimaan yang mempunyai umur tidak terbatas. Penerimaan dari sektor pajak merupakan penerimaan yang paling besar dibandingkan penerimaan dari sektor lain seperti sektor bukan pajak dan hibah.

Penerimaan pendapatan pajak agar dapat berlangsung secara maksimal tentu sangat membutuhkan kesadaran masyarakat untuk memenuhi kewajiban perpajakan yang berlaku di sebuah negara. Persoalan mengenai kepatuhan pajak merupakan suatu persoalan yang sangat penting khususnya di Indonesia karena jika wajib pajak tidak patuh maka dapat menimbulkan keinginan untuk melakukan penghindaran, pengelakan dan pelalaian pajak dimana kedepannya akan merugikan negara yaitu berkurangnya penerimaan pajak (Mangoting, 2013).

Apabila dilihat dari sudut pandang yuridis, pajak memang mengandung unsur pemaksaan. Artinya, jika kewajiban perpajakan tidak dilaksakan, maka ada konsekuensi hukum yang bisa terjadi. Konsekuensi hukum tersebut adalah pengenaan sanksi-sanksi perpajakan. Pada hakikatnya, pengenaan sanksi perpajakan tersebut diberlakukan untuk menciptakan kepatuhan wajib pajak dalam melaksanakan kewajiban perpajakannya. Maka dari itu pentingbagi wajib pajak untuk memahami sanksi-sanksi perpajakan sehingga mengetahui konsekuensi hukum atas apa yang dilakukan ataupun tidak dilakukan.

Reformasi perpajakan di Indonesia telah dilakukan pertama kali pada tahun 1983 dimana saat itu terjadi reformasi atau perubahan sistem mendasar atas pengelolaan sistem perpajakan di Indonesia dimana semula menggunakan sistem Official Assesment dan dirubah menjadi sistem Self Assesment. Tujuan atas perubahan ini adalah untuk mengurangi adanya kontak langsung Aparat Pajak dengan Wajib Pajak karena dikhawatirkan dengan adanya kontak langsung dapat menimbulkan praktek-praktek ilegal untuk mengurangi ataupun menghindarri kewajiban perpajakan para Wajib Pajak yang bersangkutan (Sarunan, 2015). 
Perubahan sistem tersebut juga membawa misi dan konsekuensi perubahan sikap (kesadaran) masyarakat untuk membayar pajak secara sukarela. Wajib pajak harus memiliki sikap kepatuhan untuk menerapkan sistem tersebut, karena hingga saat ini masih banyak masyarakat yang belum menyadari akan pentingnya sikap patuh dalam membayar pajak (Simanjuntak, 2009).

Kepatuhan wajib pajak menurut Keputusan Menteri Keuangan No. 544/KMK.04/2000 adalah suatu tindakan wajib pajak untuk memenuhi kewajiban perpajakannya sesuai dengan peraturan perundang-undangan dan peraturan pelaksanaan perpajakan yang berlaku di suatu negara. Selain itu kepatuhan wajib pajak juga didefinisikan sebagai kepatuhan wajib pajak dalam mendaftarkan diri, kepatuhan untuk melaporkan kembali Surat Pemberitahuan (SPT), kepatuhan dalam penghitungan dan melakukan pembayaran pajak terhutangnya dan kepatuhan dalam pembayaran tunggakan pajak.

Pada era globalisasi saat ini, kepatuhan wajib pajak untuk memenuhi kewajibannya sangat dipengaruhi oleh kesadaran wajib pajak yang bersangkutan. Kesadaran wajib pajak muncul dari dalam diri masing-masing dimana kesadaran tersebut muncul ketika ia mengetahui dampak apa yang terjadi apabila ia melaksanakan atau tidak melaksanakan kewajibannya. Pemerintah juga perlu melakukan upaya-upaya untuk menumbuhkan rasa kesadaran dan kepatuhan wajib pajak secara terus-menerus untuk mencapai target pajak yang telah ditetapkan salah satunya melalui media visual sehingga sangat mudah diterima oleh masyarakat luas di jaman digital seperti saat ini.

Era otonomi daerah yang secara resmi mulai diberlakukan di Indonesia sejak 1 Januari 2001 menghendaki daerah untuk berkreasi dalam memperoleh sumber penerimaan yang dapat membiayai pengeluaran pemerintah dan pembangunan daerah. Setiap daerah mempunyai hak dan kewajiban mengatur dan mengurus rumah tangganya sendiri untuk meningkatkan efisiensi dan efektivitas penyelenggaraan pemerintahan dan pelayanan kepada masyarakat, sehingga untuk menyelenggarakan pemerintahan tersebut, daerah mempunyai hak untuk mengenakan pungutan terhadap masyarakatnya. Pembiayaan pemerintah dalam melaksanakan tugas pemerintahan dan pembangunan senantiasa memerlukan sumber penerimaan yang dapat diandalkan. Kebutuhan ini semakin dirasakan oleh daerah terutama sejak diberlakukannya otomi daerah di Indonesia. Dengan adanya sistem otonomim daerah, maka lebih memicu pemerintah untuk lebih berkreasi dalam mencari sumber penerimaan daerah yang dapat mendukung pengeluaran daerah salah satunya dengan meningkatkan kesadaran masyarakat untuk memenuhi kewajibannya pajaknya (Siahaan, 2013).

Ritonga, (2012) menyatakan bahwa kesadaran wajib pajak dalam membayar pajak merupakan perilaku wajib pajak yang berupa pandangan atau perasaan yang melibatkan pengetahuan, keyakinan, dan penalaran disertai kecenderungan untuk bertindak sesuai peraturan yang diberikan oleh sistem dan ketentuan pajak tersebut.

Kesadaran wajib pajak dapat dilihat dari kesungguhan dan keinginan wajib pajak untuk memenuhi kewajiban pajaknya yang ditunjukkan dalam pemahaman wajib pajak terhadap fungsi pajak dan kesungguhan wajib pajak dalam membayar dan melaporkan pajak (Putri \& Jati, 2013). Meningkatnya kesadaran akan 
menumbuhkan motivasi wajib pajak dalam melaksanakan kewajiban perpajakannya.

Kantor Pelayanan Pajak Pratama Gianyar merupakan instansi vertikal yang berada di bawah dan bertanggung jawab langsung kepada Kepala Kantor Direktorat Jenderal Pajak Wilayah Bali. Fungsi dari kantor pelayanan pajak yakni melakukan pengumpulan dan pengolahan data, penyajian informasi perpajakan, pengamatan potensi perpajakan dan efektifitas wajib pajak, penelitian dan penatausahaan surat pemberitahuan pajak tahunan, surat pemberitahuan masa serta berkas Wajib Pajak, penerimaan pajak, penagihan, pemeriksaan, penerapan sanksi perpajakan dan pelaksanaan administarasi Kantor Pelayanan Pajak. Gambaran jumlah penerimaan pajak pada KPP Pratama Gianyar disajikan dalam Tabel 1 berikut.

Tabel 1. Laporan SPT Tahunan PPh Wajib Pajak Badan yang Masuk pada Tahun 2012-2014

\begin{tabular}{|c|c|c|c|}
\hline \multirow{2}{*}{ Uraian } & \multicolumn{3}{|c|}{ Tahun } \\
\hline & 2012 & 2013 & 2014 \\
\hline \multicolumn{4}{|l|}{ WP Badan: } \\
\hline WP Efektif & 5.115 & 5.238 & 5.993 \\
\hline WP Tidak Efektif & 582 & 584 & 584 \\
\hline SPT Masuk & 2.513 & 2.545 & 2.616 \\
\hline SPT Tidak Masuk & 2.602 & 2.693 & 3.377 \\
\hline Kepatuhan (\%) & 49,13 & 48,59 & 43,65 \\
\hline
\end{tabular}

Sumber: KPP Pratama Gianyar, 2015

Berdasarkan Tabel 1 bahwa jumlah Wajib Pajak Badan yang terdaftar mengalami peningkatan setiap tahunnya sejak tahun 2012 hingga tahun 2014, sedangkan persentase tingkat kepatuhannya pada periode tahun 2012 hingga tahun 2014 cenderung mengalami penurunan. Tabel 1 juga menunjukkan persentase kepatuhan SPT masuk dibandingkan dengan jumlah wajib pajak efektif yang terdaftar pada tahun 2012 sebesar 49,13 persen, tahun 2013, 48,59 persen, dan tahun 2014 sebesar 43,65 persen. Tingkat kepatuhan Wajib Pajak Badan di Kantor Pelayanan Pajak (KPP) Pratama Gianyar ini menunjukkan persentase tingkat kepatuhan yang masih rendah.

Rendahnya kesadaran wajib pajak yang tidak melakukannya kewajibannya kemungkinan disebabkan oleh dua faktor. Pertama, sosialisasi yang masih minim sehingga wajib pajak tidak melakukan kewajibannya dalam pembayaran pajak. Kedua, karena wajib pajak yang enggan membayar pajak karena alasan-alasan tertentu. Maka dari itu perlu dikaji lebih mendalam faktor-faktor yang memengaruhi tingkat kepatuhan Wajib Pajak di KPP Pratama Gianyar.

Penelitian untuk mengetahui pengaruh sanksi pajak dan kesadaran wajib pajak terhadap kepatuhan wajib pajak sudah banyak dilakukan, namun menimbulkan hasil yang sangat beragam untuk masing-masing penelitian yang dilakukan. Secara teoritis, sanksi pajak dan kesadaran wajib pajak dapat mempengaruhi kepatuhan wajib pajak.

Hasil penelitian yang dilakukan oleh Marjan, (2014) tentang pengaruh kesadaran wajib pajak dan sanksi pajak terhadap kepatuhan wajib pajak yaitu kesadaran wajib pajak dan sanksi pajak berpengaruh positif dan signifikan terhadap kepatuhan wajib pajak. Begitu juga penelitian yang dilakukan oleh Saputra, (2015) 
bahwa sanksi pajak dan kesadaran perpajakan berpengaruh positif signifikan terhadap kepatuhan pajak dengan studi empiris pada Wajib Pajak Kabupaten Pasaman.

Tingkat kepatuhan wajib pajak dalam melakukan kewajiban perpanjakannya ditengah berbagai kemudahan yang diberikan Direktorat Jenderal Pajak melalui pelayanan fiskus serta pemberian penyuluhan untuk memberikan pengetahuan tentang pajak dan pelaksanaan sanksi perpanjakan yang masih sangat rendah menyiratkan masih terdapat ketidakseimbangan antara langkah Direktorat Jenderal Pajak dengan tanggapan yang diberikan oleh masing-masing Wajib Pajak. Berbagai kemungkinan dapat timbul dalam hal ini, pertama seluruh langkah yang diambil oleh Direktorat Jenderal Pajak belum maksimal dan yang kedua kesadaran wajib pajak atas kewajibannya kepada negara memnag sangat jauh dari harapan. Jika dilakukan pengoptimalan dalam upaya peningkatan kepatuhan wajib pajak dalam membayar pajak, maka akan meningkatkan pendapatan negara dan pelaksanaan pembangunan di Indonesia.

Sanksi perpajakan sangat penting diberikan kepada wajib pajak dalam memenuhi kewajiban perpajakannya. Kesadaran wajib pajak akan lebih efektif jika Direktorat Jenderal Pajak memberikan sanksi perpajakan. Adanya sanksi perpajakan ini, maka wajib pajak akan mendapatkan hukuman dan pembinaan sehingga dapat meningkatkan kepatuhan wajib pajak.

Wajib pajak akan patuh jika mereka berfikir adanya sanksi berat akibat tindakan ilegal dalam usahanya menyelundupkan pajak. Penerapan sanksi perpajakan baik administrasi (denda dan bunga) dan pidana (kurungan atau penjara) mendorong kepatuhan wajib pajak, namun penerapan sanksi harus konsisten dan berlaku terhadap semua wajib pajak yang tidak memenuhi kewajiban perpajakannya. Penelitian yang dilakukan oleh Mutia, (2014) yang meneliti kepatuhan wajib pajak di KPP Pratama Padang menemukan bahwa sanksi perpajakan berpengaruh signifikan positif terhadap kepatuhan wajib pajak.

Apabila diberlakukannya sanksi kepada wajib pajak yang berusaha menyembunyikan objek pajaknya dan tidak memenuhi kewajiban perpajakannya dapat menyebabkan terpenuhinya kewajiban perpajakan wajib pajak yang bersangkutan sehingga akan meningkatkan kepatuhan wajib pajak tersebut dalam membayar pajak. Hal ini terjadi karena wajib pajak tersebut merasa terbebani atas sanksi yang diterima karena melalaikan kewajiban perpajakannya. Selain itu, wajib pajak juga akan melaksanakan kewajiban perpajakannya karena ia memahami bahwa sanksi yang akan diterima akan lebih merugikan jika dibandingkan dengan apabila wajib pajak menyelesaikan kewajiban perpajakannya sesuai dengan peraturan yang berlaku.

Sesuai uraian diatas, maka sanksi pajak berpengaruh positif terhadap kepatuhan wajib pajak. Hipotesis yang diajukan berdasarkan teori dan penelitian sebelumnya adalah:

$\mathrm{H}_{1}$ : Sanksi pajak berpengaruh positif pada kepatuhan wajib pajak.

Kesadaran wajib pajak merupakan kondisi dimana wajib pajak mengetahui, mematuhi, dan melaksanakan kewajiban perpajakan dengan benar dan sukarela. Apabila pemahaman dan pelaksanaan kewajiban perpajakan semakin baik, maka tingkat kesadaran wajib pajak semakin tinggi sehingga diharapkan dapat meningkatkan kepatuhan perpajakannya (Muliari \& Setiawan, 2011). Pernyataan ini 
didukung oleh teori kepatuhan yang dikemukakan oleh Green, (1991) bahwa kepatuhan dianggap sebagai perubahan perilaku dari perilaku mereka yang tidak menaati peraturan menjadi menaati peraturan.

Penelitian yang dilakukan oleh Putri \& Jati, (2013) dan Pratiwi \& Setiawan, (2014) menemukan bahwa kesadaran wajib pajak berpengaruh positif terhadap kepatuhan wajib pajak. Hipotesis yang diajukan berdasarkan teori dan penelitian sebelumnya adalah:

$\mathrm{H}_{2}$ : Kesadaran wajib pajak berpengaruh positif pada kepatuhan wajib pajak.

Pajak merupakan penerimaan Negara yang paling utama dan paling besar maka dari itu pajak merupakan hal yang paling penting dalam meningkatkan pembangunan nasional. Banyak definisi atau batasan pajak yang telah dikemukakan oleh para pakar, yang satu sama lain pada dasarnya memiliki tujuan yang sama yaitu merumuskan pengertian pajak sehingga mudah dimengerti. Perbedaannya hanya terletak pada sudut pandang yang digunakan oleh masingmasing pihak pada saat merumuskan pengertian pajak.

Menurut P.J. A. Andriani dalam bukunya Priantara, (2012) mendefinisikan Pajak adalah iuran masyarakat kepada Negara (yang dipaksakan) yang terhutang oleh yang wajib membayarnya menurut peraturan-peraturan umum (UndangUndang) dengan tidak mendapat prestasi kembali yang langsung dapat ditunjuk dan yang gunanya adalah untuk membiayai pengeluaran-pengeluaran umum yang berhubungan dengan tugas Negara untuk menyelenggarakan pemerintahan sedangkan menurut Rochmat Soemitro, dalam bukunya Mardiasmo, (2011), mendefinisikan pajak ialah iuran rakyat kepada kas Negara (peralihan kekayaan dari sector partikulir ke sector pemerintah berdasarkan undang-undang (dapat dipaksakan) dengan tiada mendapat jasa timbal, yang langsung dapat ditunjukkan dan digunakan untuk membiayai pengeluaran umum.

Undang-Undang Repulik Indonesia Nomor 28 Tahun 2007 tentang Ketentuan Umum dan Tata Cara Perpajakan Pasal 1 ayat 1 mendefenisikan pajak sebagai kontribusi kepada negara yang terutang oleh orang pribadi maupun badan yang bersifat memaksa berdasarkan undang-undang dengan tidak mendapatkan imbalan langsung dan digunakanuntuk keperluan negara bagi sebesar-besarnya kemakmuran rakyat.

Kepatuhan pajak adalah kepatuhan seseorang wajib pajak terhadap peraturan atau Undang-Undang Perpajakan (Arum, 2012). Kepatuhan wajib pajak merupakan pemenuhan kewajiban perpajakan yang dilakukan oleh pembayar pajak dalam rangka memberikan kontribusi bagi pembangunan dewasa ini yang diharapkan di dalam pemenuhannya diberikan secara sukarela. Kepatuhan wajib pajak merupakan sebuah aspek penting mengingat sistem perpajakan Indonesia menganut sistem Self Assesment dimana dalam prosesnya secara mutlak memberikan kepercayaan kepada wajib pajak untuk menghitung, membayar dan melaporkan kewajibannya.

Menurut Keputusan Menteri Keuangan No. 544/KMK.04/2000 dalam Devano \& Rahayu, (2010) menyatakan bahwa kepatuhan perpajakan adalah tindakan Wajib Pajak dalam pemenuhan kewajiban perpajakannua sesuai dengan ketentuan peraturan perundang-undangan dan peraturan pelaksanaan perpajakan yang berlaku dalam suatu negara. Kesadaran untuk menjadi wajib pajak yang taat dan patuh terhadap peraturan yang berlaku merupakan salah satu contoh 
kepatuhan terhadap hukum. Patuh terhadap pajak dapat disebut juga patuh terhadap hukum perpajakan dimana hukum perpajakan tidaklah pandang bulu dalam penerapannya.

Efisiensi dan efektifitas administrasi perpajakan yang lebih akurat adalah dengan mengukur berapa besarnya jurang kepatuhan (tax gap), yaitu selisih antara penerimaan yang sesungguhnya dengan pajak potensial dengan tingkat kepatuhan dari masing-masing sektor perpajakan. Kondisi perpajakan yang menuntut keikutsertaan aktif wajib pajak dalam menyelenggarakan perpajakannya membutuhkan kepatuhan wajib pajak yang tinggi yaitu kepatuhan dalam pemenuhan kewajiban perpajakan yang sesuai dengan peraturan yang berlaku.

Berdasarkan OECD (Organization for Economic Coorperation and Development) dalam Harahap, (2004) dapat diketahui bahwa perilaku-perilaku kepatuhan wajib pajak adalah bervariasi. Setiap tingkat kepatuhan dapat direspon dengan strategi kepatuhan (complience strategy) yang berbeda. Pilihan strategi kepatuhan yang dilaksanakan adalah merupakan produk dari kebijakan, masyarakat wajib pajak dibagi menjadi lima tingkatan kepatuhan.

Pada tingkatan paling baik atau ideal dimana wajib pajak sudah memiliki tingkat kesadaran yang sangat tinggi dalam melaksanakan kewajiban perpajakannya dengan baik (willing to do the right things), maka sebagai strategi kepatuhan terhadap mereka adalah upaya fiskus untuk terus-menerus memberikan kemudahan dalam pelayanan yang terbaik.

Pada tingkat kepatuhan selanjutnya adalah masyarakat wajib pajak yang selalu mencoba-coba untuk memanfaatkan peluang menghindari pajak walau tidak selalu berhasil (try to but do not always succed). Kepatuhan wajib pajak untuk menghindari pajak dapat berakibat melanggar aturan pajak. Peraturan perpajakan berupa undang-undang pajak beserta aturan pelaksanaannya dimaksudkan untuk tidak memberikan peluang untuk dapat ditafsirkan oleh siapa saja, melainkan suatu ketentuan yang pasti bagi yang melanggarkannya akan terkena sanksi sesuai ketentuan.

Tingkatan kepatuhan pajak selanjutnya adalah dimana wajib pajak tidak patuh yaitu tidak bersedia memenuhi aturan perpajakan yang berlaku (don't want to comply) wajib pajak selalu dengan aktif menghindar memenuhi kewajibannya dengan alasan yang berbeda-beda. Masalah perbedaan perlakuan pajak akibat masih dirasakannya ketidakadilan aturan, prosedur administrasi pelaporan pajak yang dirasakan masih rumit mendorong wajib pajak tidak bersedia melaksanakan kewajiban perpajakan dengan benar.

Tingkat kepatuhan pajak yang terakhir adalah sudah pada tingkat yang sama sekali tidak bersedia memenuhi kepatuhan pajak atau tidak mau membayar pajak yang menjadi kewajibannya (have decided not to comply). Segala upaya dilakukan wajib pajak untuk menghindari pajak, bahkan menyelundupkan atau menggelapkan pajak, yaitu dengan sengaja melanggar perpajakan.

\section{METODE PENELITIAN}

Penelitian ini dilakukan di Kantor Pelayanan Pajak Pratama Gianyar. Kantor Pelayanan Pajak Pratama Gianyar beralamat di Jalan Dharma Giri, Buruan Blahbatuh - Gianyar. Penelitian dilakukan di KPP Pratama Gianyar karena agar 
memudahkan peneliti untuk mendapatkan data sehubungan dengan jarak dan waktu yang dibutuhkan oleh peneliti untuk melakukan penelitian.

Objek dalam penelitian ini adalah wajib pajak badan yang melakukan kegiatan perpajakan di Kantor Pelayanan Pajak Pratama Gianyar, khususnya mengenai kesadaran wajib pajak, kepatuhan wajib pajak dan sanksi pajak.

Populasi dalam penelitian ini adalah seluruh wajib pajak badan yang terdaftar di Kantor Pelayanan Pajak Pratama Gianyar. Jumlah populasi dalam penelitian ini sangatlah banyak, mengingat keterbatasan waktu dan biaya, jumlah sampel dalam penelitian ini ditentukan dengan metode convenience sampling. Metode convenience sampling adalah pengambilan sampel yang dilakukan secara acak dengan mempertimbangkan kemudahan akses yang dapat dijangkau oleh peneliti. Dengan ukuran populasi sebanyak 6.577 dan dengan persen kelonggaran ketidaktelitian karena kesalahan pengambilan sampel yang dapat ditolerir atau diinginkan $(0,1)$ penelitian ini akan menggunakan 100 sampel. Responden dalam penelitian ini adalah 100 Wajib Pajak Badan di Kantor Pelayanan Pajak Pratama Gianyar.

Alat analisis regresi berganda digunakan untuk melihat pengaruh beberapa variabel independen terhadap variabel dependen. Persamaan regresi untuk menguji hipotesis tersebut adalah sebagai berikut:

$$
\mathrm{Y}=\mathrm{a}+\mathrm{b}_{1} \mathrm{X}_{1}+\mathrm{b}_{2} \mathrm{X}_{2}+\mathrm{e} \text {. }
$$

\section{Keterangan:}

Y

a

$b_{1}, b_{2}$

$\mathrm{X}_{1}$

$\mathrm{X}_{2}$

$\mathrm{e}$
= Kepatuhan Wajib Pajak

= Konstanta

$=$ Koefisien Regresi

=Sanksi Perpajakan

=Kesadaran Wajib Pajak

$=$ Standar Eror (Nilai Residu)

Berdasarkan hasil analisis yang dilakukan dapat diamati mengenai koefisien determinasi $\left(R^{2}\right)$, uji kelayakan model (uji F), dan uji hipotesis (uji t).

\section{HASIL DAN PEMBAHASAN}

Deskripsi variabel penelitian menjabarkan informasi masing-masing variabel penelitian dan statistik deskriptif masing-masing variabel untuk memberikan gambaran tentang karakteristik masing-masing variabel penelitian, antara lain mean, minimum, maksimum dan standar deviasi. Pengukuran rata-rata (mean) merupakan cara yang paling umum digunakan untuk mengukur nilai sentral suatu distribusi data. Nilai minimum merupakan nilai yang paling rendah dari suatu distribusi data.Nilai maksimum merupakan nilai yang tertinggi dari suatu distribusi data.Sedangkan standar deviasi adalah perbedaan nilai data yang diteliti dengan nilai rata-rata. Hasil lengkapnya dapat dilihat pada Tabel 2 berikut:

Tabel 2. Hasil Statistik Deskriptif

\begin{tabular}{llcccc}
\hline & N & Minimum & Maximum & Mean & Std. Deviation \\
\hline X1 & 100 & 16,00 & 20,00 & 19,0100 & 1,08707 \\
X2 & 100 & 19,00 & 24,00 & 21,8600 & 1,31056 \\
Y & 100 & 14,00 & 18,00 & 16,8000 & 0,85280 \\
Valid N & 100 & & & & \\
\hline
\end{tabular}

Sumber: Data Penelitian, 2018 
Berdasarkan statistik deskriptif sesuai dengan Tabel 2 diperoleh nilai minimum dari sanksi pajak sebesar 16 sedangkan nilai maksimum sebesar 20. Nilai rata-rata dari sanksi pajak sebesar 19,01 dan standar deviasi sebesar 1,08.

Berdasarkan statistik deskriptif sesuai dengan Tabel 2 diperoleh nilai minimum dari kesadaran wajib pajak sebesar 19 sedangkan nilai maksimum sebesar 24. Nilai rata-rata dari kesadaran wajib pajak sebesar 21,8 dan standar deviasi sebesar 1,3.

Berdasarkan statistik deskriptif sesuai dengan Tabel 2 diperoleh nilai minimum dari kepatuhan wajib pajak sebesar 14 sedangkan nilai maksimum sebesar 18. Nilai rata-rata dari kepatuhan wajib pajak sebesar 16,80 dan standar deviasi sebesar 0,85 .

Uji validitas merupakan pengujian instrumen penelitian sebagai suatu derajat ketepatan alat ukur penelitian tentang inti atau arti sebenarnya yang diukur.Tinggi rendahnya validitas menunjukkan sejauh mana data yang terkumpul tidak menyimpang dari gambaran tentang variabel yang dimaksud. Pengujian validitas tiap butir menggunakan analisis item yaitu, mengkorelasikan skor tiap butir atau faktor dengan skor total yang merupakan jumlah tiap skor butir. Syarat minimum suatu kuisioner untuk memenuhi validitas adalah jika korelasi antara butir dengan skor total tersebut positif dan nilainya lebih besar dari 0,30. Adapun hasil dari uji validitas dapat ditunjukkan pada Tabel 3 berikut.

Tabel 3. Hasil Uji Validitas

\begin{tabular}{cccc}
\hline Variabel & Indikator & Koefisien Korelasi & Keterangan \\
\hline Sanksi pajak & X1.1 & 0,683 & Valid \\
& X1.2 & 0,762 & Valid \\
X1.3 & 0,550 & Valid \\
& X1.4 & 0,665 & Valid \\
& X1.5 & 0,683 & Valid \\
Kesadaran wajib pajak & X2.1 & 0,760 & Valid \\
& X2.2 & 0,799 & Valid \\
& X2.3 & 0,689 & Valid \\
X2.4 & 0,695 & Valid \\
& X2.5 & 0,653 & Valid \\
& X2.6 & 0,695 & Valid \\
Kepatuhan wajib pajak & Y1 & 0,783 & Valid \\
& Y2 & 0,818 & Valid \\
& Y3 & 0,717 & Valid \\
& Y4 & 0,826 & Valid \\
& Y5 & 0,805 & Valid \\
\hline
\end{tabular}

Sumber: Data Penelitian, 2018

Berdasarkan Tabel 3, instrumen-instrumen pada setiap variabel dalam penelitian ini memiliki nilai korelasi diatas 0,30 sehingga dapat disimpulkan bahwa, seluruh butir dalam instrumen penelitian ini dikatakan valid atau dapat dinyatakan layak digunakan sebagai alat ukur.

Reliabilitas adalah derajat ketepatan, ketelitian atau keakuratan yang ditunjukkan oleh instrument pengukuran dimana pengujiannya dapat dilakukan secara internal, yaitu pengujian dengan menganalisis konsistensi butir-butir yang ada. Adapun hasil dari uij realibilitas dapat ditunjukkan pada Tabel 4. 
Tabel 4. Hasil uji reliabilitas

\begin{tabular}{clcc}
\hline No. & \multicolumn{1}{c}{ Variabel } & Cronbach's Alpha & Keterangan \\
\hline 1. & Sanksi pajak & 0,661 & Reliabel \\
2. & Kesadaran wajib pajak & 0,803 & Reliabel \\
3. & Kepatuhan wajib pajak & 0,848 & Reliabel \\
\hline
\end{tabular}

Sumber: Data Penelitian, 2018

Berdasarkan Tabel 4, nilai Cronbach's Alpha untuk setiap variabel lebih besar dari 0,6. Jadi, dapat dinyatakan bahwa seluruh variabel telah memenuhi syarat reliabilitas atau dapat dikatakan reliabel sehingga, dapat digunakan untuk melakukan penelitian.

Uji normalitas bertujuan untuk menguji apakah variabel residual dalam model regresi penelitian ini mempunyai distribusi normal atau tidak normal.Pengujian normalitas dalam penelitian ini menggunakan uji statistik Kolmogorov-Smirnov (K-S).Hasil pengujian normalitas dapat dilihat pada Tabel 5 sebagai berikut.

Tabel 5. Hasil Uji Normalitas

\begin{tabular}{lrr}
\hline & & $\begin{array}{r}\text { Unstandardiz } \\
\text { ed Residual }\end{array}$ \\
\hline$N$ & & 100 \\
Normal Parameters $a, b$ & Mean &, 0000000 \\
& Std. Deviation &, 33733432 \\
Most Extreme & Absolute &, 099 \\
Differences & Positive &, 099 \\
& Negative &,- 073 \\
Kolmogorov-Smirnov Z & &, 995 \\
Asymp. Sig. (2-tailed) & &, 276 \\
\hline
\end{tabular}

Sumber: Data Penelitian, 2018

Berdasarkan Tabel 5 dapat dilihat bahwa nilai Kolmogorov-Smirnov (K-S) adalaah 0,995 dan nilai asymp.Sig (2-tailed) sebesar 0,276. Nilai tersebut menunjukkan bahwa secara statistik nilai Asymp.sig (2-tailed) lebih besar dari 0,05 yang berarti data terdistribusi secara normal.

Uji Multikolinearitas bertujuan untuk menguji apakah di dalam model regresi ditemukan adanya korelasi antar variabel bebas. Model regresi yang baik seharusnya tidak terjadi korelasi diantara variabel bebas. Suatu model regresi dapat dikatakan baik jika tidak terjadi multikolinearitas di dalamnya. Model regresi yang bebas dari multikolinearitas adalah yang memiliki nilai variance inflaction factor (VIF) tidak lebih dari 10 dan mempunyai angka tolerance lebih dari $10 \%$.

Tabel 6. Hasil Uji Multikolinearitas

\begin{tabular}{|c|c|c|c|}
\hline & & Collinearity Statistics & \\
\hline Model & & Tolerance & VIF \\
\hline \multirow[t]{2}{*}{1} & $\mathrm{X} 1$ & 997 & 1,003 \\
\hline & $\mathrm{X} 2$ & 997 & 1,003 \\
\hline
\end{tabular}

Sumber: Data Penelitian, 2018

Berdasarkan hasil pengujian yang ditunjukkan pada Tabel 6, nilai tolerance variabel bebas lebih dari $10 \%$ atau 0,1 dimana nilai tolerance dari dibawah 10 . Dengan demikian dapat disimpulkan tidak terjadi multikolinearitas diantara variabel bebas dalam penelitian ini. 
Uji heteroskedastisitas dilakukan untuk mengetahui apakah dalam model regresi terjadi ketidaksamaan varian.Uji ini dapat dianalisis melalui uji gletser dengan melihat tingkat signifikansi, jika tingkat signifikansi berada di atas 0,05 maka model regresi ini bebas dari masalah heteroskedastisitas.

Tabel 7. Uji Heterokedastisitas

\begin{tabular}{llrrrrrr}
\hline & & \multicolumn{2}{c}{$\begin{array}{c}\text { Unstandardized } \\
\text { Coefficients }\end{array}$} & \multicolumn{2}{c}{$\begin{array}{c}\text { Standardized } \\
\text { Coefficients }\end{array}$} & & \\
\cline { 3 - 5 } Model & & $B$ & Std. Error & Beta & $t$ & \multicolumn{1}{c}{ Sig. } \\
\hline 1 & (Constant) &, 463 &, 549 & & &, 843 &, 401 \\
& X1 &,- 006 &, 020 &,- 028 &,- 275 &, 784 \\
& X2 &,- 005 &, 017 &,- 028 &,- 272 &, 786 \\
\hline
\end{tabular}

Sumber: Data Penelitian, 2018

Berdasarkan hasil pengujian yang ditunjukkan pada Tabel 7, tingkat signifikansi berada di atas 0,05. Dengan demikian dapat dikatakan bahwa dalam model regresi ini tidak terdapat heterokedastisitas.

Uji kesesuaian model (uji F) dimaksudkan dalam rangka mengetahui apakah dalam penelitian ini model yang digunakan layan untuk digunakan atau tidak sebagai alat analisis untuk menguji pengaruh variabel independen pada variabel dependennya. Hasil pengujian disajikan dalam Tabel 8 sebagai berikut.

Tabel 8. Hasil uji Kesesuaian Model

\begin{tabular}{llrrrrr}
\hline Model & & $\begin{array}{c}\text { Sum of } \\
\text { Squares }\end{array}$ & df & Mean Square & \multicolumn{1}{c}{$F$} & \multicolumn{1}{c}{ Sig. } \\
\hline 1 & Regression & 60,734 & 2 & 30,367 & 261,496 & ,000a \\
& Residual & 11,266 & 97 &, 116 & & \\
& Total & 72,000 & 99 & & & \\
\hline
\end{tabular}

Sumber: Data Penelitian, 2018

Berdasarkan Tabel 8 dapat dilihat bahwa pada model memiliki nilai sig sebesar 0,00 lebih kecil dari nilai $\alpha=0,05$ menunjukkan model penelitian ini layak untuk digunakan sebagai alat analisis untuk menguji pengaruh variabel independen terhadap variabel independen. Hal ini dapat dikatakan bahwa variabel sanksi pajak, dan kesadaran wajib pajak berpengaruh secara bersama-sama terhadap variabel dependennya yaitu kepatuhan wajib pajak.

Analisis koefisien determinasi dilakukan untuk mengukur seberapa besar variabel bebas mampu menjelaskan perubahan variabel terikatnya.Pada penelitian ini koefisien determinasi dilihat melalui nilai $\mathrm{R}^{2}$ yang terlihat pada Tabel 9 sebagai berikut.

Tabel 9. Hasil Koefisien Determinasi Model

\begin{tabular}{|c|c|c|c|c|}
\hline Model & $\mathrm{R}$ & R Square & $\begin{array}{c}\text { Adjusted } \\
\text { R } \\
\text { Square }\end{array}$ & $\begin{array}{c}\text { Std. Error of } \\
\text { The } \\
\text { Estimate }\end{array}$ \\
\hline 1 & $918^{a}$ & 844 & 840 & ,34079 \\
\hline
\end{tabular}

Sumber: Data Penelitian, 2018

Berdasarkan Tabel 9 dapat dilihat bahwa nilai $\mathrm{R}^{2}$ pada model sebesar 0,844. Nilai R 2 Pada model yang artinya 84,4 persen perubahan kepatuhan wajib pajak dapat dijelaskan oleh variabel sanksi pajak, kesadaran wajib pajak dan kesadaran wajib pajak.

Uji statistik $\mathrm{t}$ pada dasarnya dilakukan untuk menunjukkan pengaruh variabel independen secara individual dalam menerangkan variabel variabel 
dependen. Uji statistik dilakukan dengan membandingkan hasil nilai signifikasi dengan $\alpha=0,05$ dan dapat dijelaskan sebagai berikut.

Tabel 10. Hasil Analisis Uji t

\begin{tabular}{ccccc}
\hline Variabel & $\begin{array}{c}\text { Koefisien } \\
\text { Regresi }\end{array}$ & thitung & sig & Hasil Hipotesis \\
\hline $\mathrm{X}_{1}$ & 0,345 & 10,956 & 0,000 & $\mathrm{H}_{0}$ ditolak \\
$\mathrm{X}_{2}$ & 0,541 & 20,652 & 0,000 & $\mathrm{H}_{0}$ ditolak \\
\hline
\end{tabular}

Sumber: Data Penelitian, 2018

Berdasarkan Tabel 10 diperoleh nilai signifikasi uji $t$ satu sisi untuk variabel sanksi pajak sebesar 0,000 maka tingkat signifikasi t pada uji satu sisi adalah 0,000 lebih kecil dari $\alpha=0,05$ dan nilai koefisien regresi sebesar 0,261 hal ini mengindikasikan bahwa sanksi pajak berpengaruh positif dan signifikan pada kepatuhan wajib pajak sehingga hipotesis pertama dalam penelitian ini diterima.

Berdasarkan Tabel 10 diperoleh nilai signifikasi uji t satu sisi untuk variabel kesadaran wajib pajak sebesar 0,00 maka tingkat signifikasi t pada uji satu sisi adalah 0,00 lebih kecil dari $\alpha=0,05$ dan nilai koefisien regresi sebesar 0,541 hal ini mengindikasikan bahwa kesadaran wajib pajak berpengaruh positif dan signifikan pada kepatuhan wajib pajak sehingga hipotesis kedua dalam penelitian ini diterima.

Berdasarkan hasil penelitian menunjukkan bahwa sanksi pajak berpengaruh positif dan signifikan pada kepatuhan wajib pajak sehingga hipotesis pertama dalam penelitian ini diterima.Hasil penelitian memberikan makna bahwa semakin tinggi sanksi pajak, maka semakin tinggi tingkat kepatuhan wajib pajak, begitu juga sebaliknya semakin rendah sanksi pajak maka semakin rendah tingkat kepatuhan wajib pajak.

Sanksi perpajakan sangat penting diberikan kepada wajib pajak dalam memenuhi kewajiban perpajakannya. Kesadaran wajib pajak akan lebih efektif jika Direktorat Jenderal Pajak memberikan sanksi perpajakan. Adanya sanksi perpajakan ini, maka wajib pajak akan mendapatkan hukuman dan pembinaan sehingga dapat meningkatkan kepatuhan wajib pajak.

Wajib pajak akan patuh jika mereka berfikir adanya sanksi berat akibat tindakan ilegal dalam usahanya menyelundupkan pajak. Penerapan sanksi perpajakan baik administrasi (denda dan bunga) dan pidana (kurungan atau penjara) mendorong kepatuhan wajib pajak, namun penerapan sanksi harus konsisten dan berlaku terhadap semua wajib pajak yang tidak memenuhi kewajiban perpajakannya. Penelitian yang dilakukan oleh Mutia, (2014) yang meneliti kepatuhan wajib pajak di KPP Pratama Padang menemukan bahwa sanksi perpajakan berpengaruh signifikan positif terhadap kepatuhan wajib pajak.

Apabila diberlakukannya sanksi kepada wajib pajak yang berusaha menyembunyikan objek pajaknya dan tidak memenuhi kewajiban perpajakannya dapat menyebabkan terpenuhinya kewajiban perpajakan wajib pajak yang bersangkutan sehingga akan meningkatkan kepatuhan wajib pajak tersebut dalam membayar pajak. Hal ini terjadi karena wajib pajak tersebut merasa terbebani atas sanksi yang diterima karena melalaikan kewajiban perpajakannya. Selain itu, wajib pajak juga akan melaksanakan kewajiban perpajakannya karena ia memahami bahwa sanksi yang akan diterima akan lebih merugikan jika dibandingkan dengan apabila wajib pajak menyelesaikan kewajiban perpajakannya sesuai dengan peraturan yang berlaku. 
Berdasarkan hasil penelitian menunjukkan bahwa kesadaran wajib pajak berpengaruh positif dan signifikan pada kepatuhan wajib pajak sehingga hipotesis kedua dalam penelitian ini diterima.Hasil penelitian memberikan makna bahwa semakin tinggi kesadaran wajib pajak, maka semakin tinggi tingkat kepatuhan wajib pajak, begitu juga sebaliknya semakin rendah kesadaran wajib pajak maka semakin rendah tingkat kepatuhan wajib pajak

Kesadaran wajib pajak merupakan kondisi dimana wajib pajak mengetahui, mematuhi, dan melaksanakan kewajiban perpajakan dengan benar dan sukarela. Apabila pemahaman dan pelaksanaan kewajiban perpajakan semakin baik, maka tingkat kesadaran wajib pajak semakin tinggi sehingga diharapkan dapat meningkatkan kepatuhan perpajakannya (Muliari \& Setiawan, 2011). Pernyataan ini didukung oleh teori kepatuhan yang dikemukakan oleh Green, (1991) bahwa kepatuhan dianggap sebagai perubahan perilaku dari perilaku mereka yang tidak menaati peraturan menjadi menaati peraturan.

Penelitian yang dilakukan oleh Putri \& Jati, (2013) dan Pratiwi \& Setiawan, (2014) menemukan bahwa kesadaran wajib pajak berpengaruh positif terhadap kepatuhan wajib pajak.

Sanksi Perpajakan merupakan alat pencegahan (preventif) agar wajib pajak tidak melanggar norma perpajakan, karena itu peningkatan pemahaman masyarakat melalui peningkatan sosialisasi dan realisasi atas sanksi yang diberlakukan diharapkan akan dapat meningkatkan intensi kepatuhan wajib pajak dalam menjalankan kewajibannya sebagai warga negara yang baik.

Dengan meningkatnya pengetahuan perpajakan masyarakat melalui pendidikan perpajakan baik formil maupun non formal akan berdampak positif terhadap pemahaman kesadaran wajib pajak dalam membayar pajak. Dengan penyuluhan perpajakan secara intensif dan berkelanjutan akan meningkatkan pemahaman wajib pajak tentang kewajiban membayar pajak sebagai wujud gotong royong nasional dalam menghimpun dana untuk pembiayaan pemerintah dan pembangunan nasional.

Ketika wajib pajak telah memiliki pemahaman yang baik mengenai pembayaran pajak serta sanksi yang akan diterima apabila wajib pajak mengabaikannya, maka wajib pajak secara prakteknya akan secara rutin membayar pajak sesuai dengan ketentuan yang berlaku sehingga pemasukan pemerintah akan mencukupi untuk pembangunan nasional dan pada akhirnya akan mensejahterakan kehidupan masyarakat.

\section{SIMPULAN}

Sanksi pajak berpengaruh positif pada kepatuhan wajib pajak. Hal ini berarti semakin meningkat sanksi pajak maka kepatuhan wajib pajak semakin tinggi. Kesadaran wajib pajak berpengaruh positif pada kepatuhan wajib pajak. Hal ini berarti semakin meningkat kesadaran wajib pajak maka kepatuhan wajib pajak semakin tinggi.

Sanksi pajak wajib disosialisasikan dengan baik kepada wajib pajak sehingga wajib pajak dapat memahami hal-hal yang berkaitan dengan pelaksanaan sanksi pajak serta penyebab dikenakan sanksi pajak terhadap wajib pajak. Sosialisasi dapat dilakukan dengan memberikan penyuluhan secara gratis bagi 
wajib pajak atau secara berkala mengirimkan pemberitahuan mengenai pelaksanaan sanksi pajak.

Perlu dilakukan sosialisasi sikap sadar membayar pajak di masyarakat. Sosialisasi dapat dilakukan melalui iklan televisi, radio maupun surat kabar serta media sosial lainnya.

Bagi peneliti selanjutnya penulis memberikan saran untuk memperluas populasi penelitian yaitu dengan menambah jumlah responden yang terdaftar pada Kantor Pajak Pratama Gianyar di Kabupaten Gianyar. Guna memperoleh tanggapan dan kesimpulan yang berbeda untuk menambah wawasan.

Mengevaluasi pertanyaan kuisioner agar pertanyaan-pertanyaan tersebut dapat mewakili secara tepat variable yang hendak diukur. Penulis juga menyarankan agar mencari indikator lain yang digunakan untuk mengukur variable-variabel yang diteliti.

\section{REFERENSI}

Arum, H. P. (2012). Pengaruh Kesadaran Wajib Pajak Pelayanan Fiskus,dan Sanksi Pajak Orang Pribadi yang Melakukan Kegiatan Usaha dan Pekerjaan Bebas. Jurnal Akuntansi Universitas Diponegoro Semarang, 1(2010), 1-8.

Devano, S., \& Rahayu, S. K. (2010). Perpajakan: Konsep, Teori, dan Isu. Jakarta: Prenada Media Group.

Green, L. (1991). Precede-Proceed Framework. Colombia: My Field Publishing Company.

Harahap, A. (2004). Paradigma Baru Perpajakan Indonesia. Jakarta: Integirtas Dinamika Press.

Mangoting, A. O. F. dan Y. (2013). Pengaruh Kualitas Pelayanan Petugas Pajak, Sanksi Perpajakan dan Biaya Kepatuhan Pajak Terhadap Kepatuhan Wajib Pajak UMKM. Tax \& Accounting Review, 1(1), 18-27.

Mardiasmo. (2011). Perpajakan Edisi Revisi. Yogyakarta: Andi.

Marjan, R. M. (2014). Pengaruh Kesadaran Wajib Pajak, Pelayanan Fiskus, dan Sanksi Pajak terhadap Tingkat Kepatuhan Formal Wajib Pajak (Studi di Kantor Pelayanan Pajak Pratama Makassar Selatan). Skripsi .Jurusan Akuntansi Fakultas Ekonomi dan Bisnis Universitas Hasanuddin. Universitas Hasanuddin.

Muliari, N. K., \& Ery Setiawan, P. (2011). Pengaruh Persepsi Tentang Sanksi Perpajakan Dan Kesadaran Wajib Pajak Pada Kepatuhan Pelaporan Wajib Pajak Orang Pribadi di Kantor Pelayanan Pajak Pratama Denpasar Timur. Jurnal Ilmiah Akuntansi Dan Bisnis, 6(1), 1-23.

Mutia, S. P. T. (2014). Pengaruh Sanksi Pajak, Kesadaran Wajib Pajak, Pelayanan Fiskus, dan Tingkat Pemahaman Tethadap Kepatuhan Wajib Pajak Orang Pribadi. Jurnal Akuntansi Universitas Negeri Padang, 2(1), 1-30.

Pratiwi, I. G. A. M. A. M. A., \& Setiawan, P. E. (2014). Pengaruh Kesadaran Wajib Pajak, Kualitas Pelayanan, Kondisi Keuangan Perusahaan, dan Persepsi tentang Sanksi Perpajakan pada Kepatuhan Wajib Pajak Reklame di Dinas Pendapatan Kota Denpasar. E-Jurnal Akuntansi Universitas Udayana, 6(1), 139153.

Priantara, D. (2012). Perpajakan Indonesia (2nd ed.). Jakarta: Mitra Wacana Media.

Putri, A. R. S., \& Jati, I. K. (2013). Faktor-Faktor Yang Mempengaruhi Kepatuhan Wajib Pajak Dalam Membayar Pajak Kendaraan Bermotor Di Denpasar. E- 
Jurnal Akuntansi Universitas Udayana, 2(2011), 1-17.

Ritonga, P. (2012). Analisis Pengaruh Kesadaran dan Kepatuhan Wajib Pajak Terhadap Kinerja Kantor Pelayanan Pajak (KPP) dengan Pelayanan Wajib Pajak Sebagai Variabel Intervening di KPP Medan Timur. Jurnal Ekonomi Dan Bisnis Islami, 2(5), 951-970.

Santika, K. A. (2015). Pengaruh Kesadaran WP, Kualitas Pelayanan, Dan Sanksi Perpajakan Pada Kepatuhan WP Air Tanah. E-Jurnal Akuntansi Universitas Udayana, 12(3), 656-670.

Saputra, R. (2015). Pengaruh Sanksi, Kesadaran Perpajakan, dan Kualitas Pelayanan Wajib Pajak terhadap Kepatuhan Wajib Pajak Bumi dan Bangunan (Studi Empiris pada Wajib Pajak Kabupaten Pasaman). Skripsi. Sarjana Akuntansi Fakultas Ekonomi Universitas Negeri Padang.

Sarunan, W. K. (2015). The Effect of Modernization on Tax Administration System To Obedience of Individual Taxpayer And Tax Payer I The Primary Tax Office Manado. Jurnal EMBA, 3(4), 518-526.

Siahaan, M. (2013). Pajak Daerah dan Retribusi Daerah (2nd ed.). Jakarta: PT Raja Grafindo Persada.

Simanjuntak, T. H. (2009). Kepatuhan Pajak (Tax Compliance) dan Bagi Hasil Pajak dalam Perekonomian di Jawa Timur. Jurnal Ekonomi E Studi Pembangunan, 1(2), $1-11$. 